\title{
Late Pleistocene climate at the northern Iberian Peninsula: New insights from palaeoglaciers at Fuentes Carrionas (Cantabrian Mountains)
}

\author{
RAMÓN PELLITERO, (D) JOSÉ M. FERNÁNDEZ-FERNÁNDEZ, NÉSTOR CAMPOS, ENRIQUE SERRANO and
} ALFONSO PISABARRO

Universidad Nacional de Educacion a Distancia

Received 25 June 2018; Revised 20 February 2019; Accepted 1 April 2019

\section{Introduction}

\section{Late Pleistocene glaciation in the Iberian Peninsula}

Late Pleistocene climatic shifts had clear impacts on glaciation of the Southern Europe mountains (Hughes and Woodward, 2017), most of which are fully deglaciated at present (Hughes, 2018). Several mountain ranges of the Iberian Peninsula underwent glaciation during this stage. The most extensively glaciated range was the Pyrenees, which is also the area where most glacial advance phases can be identified. Here, during the Local Maximum ice Extension (LME), an icefield glaciation style developed, from which only their highest peaks remained ice-free, and glaciers extended beyond the mountains, reaching lower altitudes on the Atlantic side. The LME has been dated as early as $171 \pm 22 \mathrm{ka}$ in the Aragón Valley (South Central Pyrenees, García-Ruiz et al., 2013) and $79 \pm 14.3 \mathrm{ka}$ in the Ariége catchment (Northeast Pyrenees, Delmas et al., 2011). A second and extensive icefield-style advance phase took place around $20 \mathrm{ka}$ (Calvet et al., 2011). However, this advance is neither clear at the Northwest Pyrenees, nor has it been identified in some southern valleys, e.g. the Gállego valley (Palacios et al., 2015). Oldest Dryas (OD, GS-2a stadial, 17.5-14.5 ka, Palacios et al., 2016) and Younger Dryas (YD, 13-12 ka, Rasmussen et al., 2014) glaciers have also been mapped and dated (Palacios et al., 2015; García-Ruiz et al., 2016). These more limited advance phases developed mostly valley and cirque glaciers, respectively. Finally, during the Little Ice Age (LIA), small cirque glaciers developed at the highest peaks, from which some ice remnants still exist today (González-Trueba et al., 2008).

Glaciation in the Central Range of the Iberian Peninsula LME has been reported at the 23-19 ka chronozone in Gredos (Palacios et al., 2012). However, an LME coincident with the Last Glacial Maximum (LGM; 23-28 ka, according to Hughes and Gibbard, 2015) was identified for the nearby Sierra de Béjar (Domínguez-Villar et al., 2013; Carrasco et al., 2015), with a second advance phase around $20 \mathrm{ka}$. South of the
Iberian Peninsula, in the Sierra Nevada, a pre-LGM LME was also observed and dated to around 30 ka (Gómez-Ortiz et al., 2015). Three more glacial advance phases were identified at the LGM, OD and YD, respectively (Palacios et al., 2016). Only one small cirque glacier developed at the LIA (GómezOrtiz et al., 2015). Apart from these aforementioned cases and from the Cantabrian Mountains, only marginal glaciation developed in the Central and South Iberian Peninsula (Fernández-Fernández et al., 2017).

The Cantabrian Mountains, at the north-northwest tip of the Iberian Peninsula, showed a distinctive pattern of comparatively low and extensive glaciation, fed by the moist air masses coming from the Atlantic Sea and the Bay of Biscaye. Large valley glaciers, ice caps and ice fields developed at low altitudes in the northwest, such as those in the Serra de Xistral (whose peaks are just above $1000 \mathrm{~m}$, Pérez-Alberti and Valcárcel-Díaz, 1998); the Sanabria area (with an extensive $475-\mathrm{km}^{2}$ ice cap, Rodríguez-Rodríguez et al., 2014, the largest glacier in the northwest Iberian Peninsula) or the Sil Valley ice field (the second largest in the region, of $450 \mathrm{~km}^{2}$, SantosGonzález et al., 2013). Likewise, in the northeast, lowelevation ice fields also grew thanks to the proximity of the Bay of Biscay, such as the Castro Valnera or Aralar ice fields (Serrano et al., 2015). Even today, the Cantabrian Mountains are among the wettest and most heavily snowed areas in the Iberian Peninsula, with annual precipitation generally over 1000 and even $2200 \mathrm{~mm}$ in the aforementioned Aralar and Castro Valnera mountains, and winter monthly maximum precipitation (AEMET-IM, 2011).

Recent studies of the glacial record of the Cantabrian Mountains suggest the occurrence of four glacial advances during the Late Pleistocene (Rodríguez-Rodríguez et al., 2017 and references therein): (i) a glacial maximum stage between 36 and 45 ka BP [Marine Isotope Stage (MIS) 3] (Serrano et al., 2013, 2016), also dated before $32.7 \mathrm{ka}$ in the Picos de Europa (Ruiz-Fernández et al., 2016) and at 40.4 ka by JiménezSánchez and Farias (2002); (ii) a subsequent glacial advance at 
19-23 ka BP, coeval with or slightly later than the global LGM of MIS 2 (Rodríguez-Rodríguez et al., 2016); (iii) an advance phase during the OD (17.5-14.5 ka), roughly coeval with Heinrich event 1 (Palacios et al., 2016); and (iv) a reduced, cirque glacier advance during the YD (12.9-11.7 ka) (GarcíaRuiz et al., 2016 and references therein). Rodríguez-Rodríguez et al. (2016) pointed to an older, MIS-5d LME (113.9 $\pm 7.1 \mathrm{ka})$, by dating erratics on areas where clear moraines have been eroded. Finally, some small cirque glaciers developed during the LIA in the Picos de Europa (González-Trueba et al., 2008).

Some previous dates on glacial deposits have also been performed in the Fuentes Carrionas (FC). The Naranco Valley LME moraine was dated to $36.03 \pm 2.35$ ka based on optically stimulated luminescence (Serrano et al., 2013), whereas a lacustrine deposit immediately upstream of the Naranco frontal moraine complex was dated to 16 900-16 $740{ }^{14} \mathrm{C}$ cal a BP (Serrano et al., 2013), indicating a moment when the glacier did not fill the valley. Both dates provide a broad framework for FC glaciation, which we intend to improve upon in this paper. Nevertheless, older, more extensive glaciations, whose deposits would have been completely obliterated, cannot be dismissed for FC.

Besides contributing to a better understanding of Cantabrian Mountains glaciation by adding new cosmogenic dates to the FC area, this paper offers a palaeoclimatic scenario from glacier reconstruction. Palaeoglaciers can be used to retrieve the precipitation regime in which they developed, if the temperature is known from a different proxy (Mackintosh et al., 2017). The resulting palaeoprecipitation data can be used by palaeoclimate modellers, such that southbound migration of Westerlies across Western Europe during glacial advance stages can be tracked. In addition, this paper should help to confirm, correct or disprove some of the palaeoenvironmental reconstruction scenarios already proposed for the Late
Pleistocene, by assessing the feasibility of glacier subsistence under such climatic conditions.

\section{Regional setting}

FC is the second highest massif within the Cantabrian Mountains, after the Picos de Europa. The study area lies above $1000 \mathrm{~m}$ a.s.l., with peaks generally above $2200 \mathrm{~m}$. Peña Prieta, located at the centre of the massif, is the highest point at $2539 \mathrm{~m}$. This massif is nowadays the watershed between the Deva catchment, which drains towards the Cantabrian Sea to the north, and the Duero basin to the south. Northbound valleys are usually steep due to their proximity to the sea, whereas southbound valleys are generally open and gentle, as most of the Duero basin sits on a plateau over $700 \mathrm{~m}$. Overall, there are five main valleys, all of which were occupied by glaciers during the Late Pleistocene (Fig. 1): Naranco and Lechada to the northwest; Riofrío to the northeast; and Carrión and Cardaño to the south and southeast, respectively.

Climate in the study area is not well known, especially at the peaks, as there are no weather stations within its limits. However, there is a clear contrast between the weather stations north and south of the study area. Northern valleys are more influenced by the nearby Cantabrian Sea, so they are generally subject to high precipitation year round. Santander $\left(43.46^{\circ} \mathrm{N},-3.80^{\circ} \mathrm{W}, 0 \mathrm{~m}\right)$ has average annual precipitation (AAP) of 1073-mm; mean annual air temperature (MAAT) is $14.1^{\circ} \mathrm{C}$, with seasonality (difference in average temperature of the warmest and coldest month) of $9.3^{\circ} \mathrm{C}$. Southern have a more continental climate, with precipitation clustered in winter and spring, summer aridity and higher seasonality. Guardo $\left(42.78^{\circ} \mathrm{N},-4.84^{\circ} \mathrm{W}, 1100 \mathrm{~m}\right.$.) has an AAP of $1012 \mathrm{~mm}$, whereas its MAAT is $9.2^{\circ} \mathrm{C}$; seasonality $15.7^{\circ} \mathrm{C}$. Triollo, at the southern tip of the Carrión glacial valley

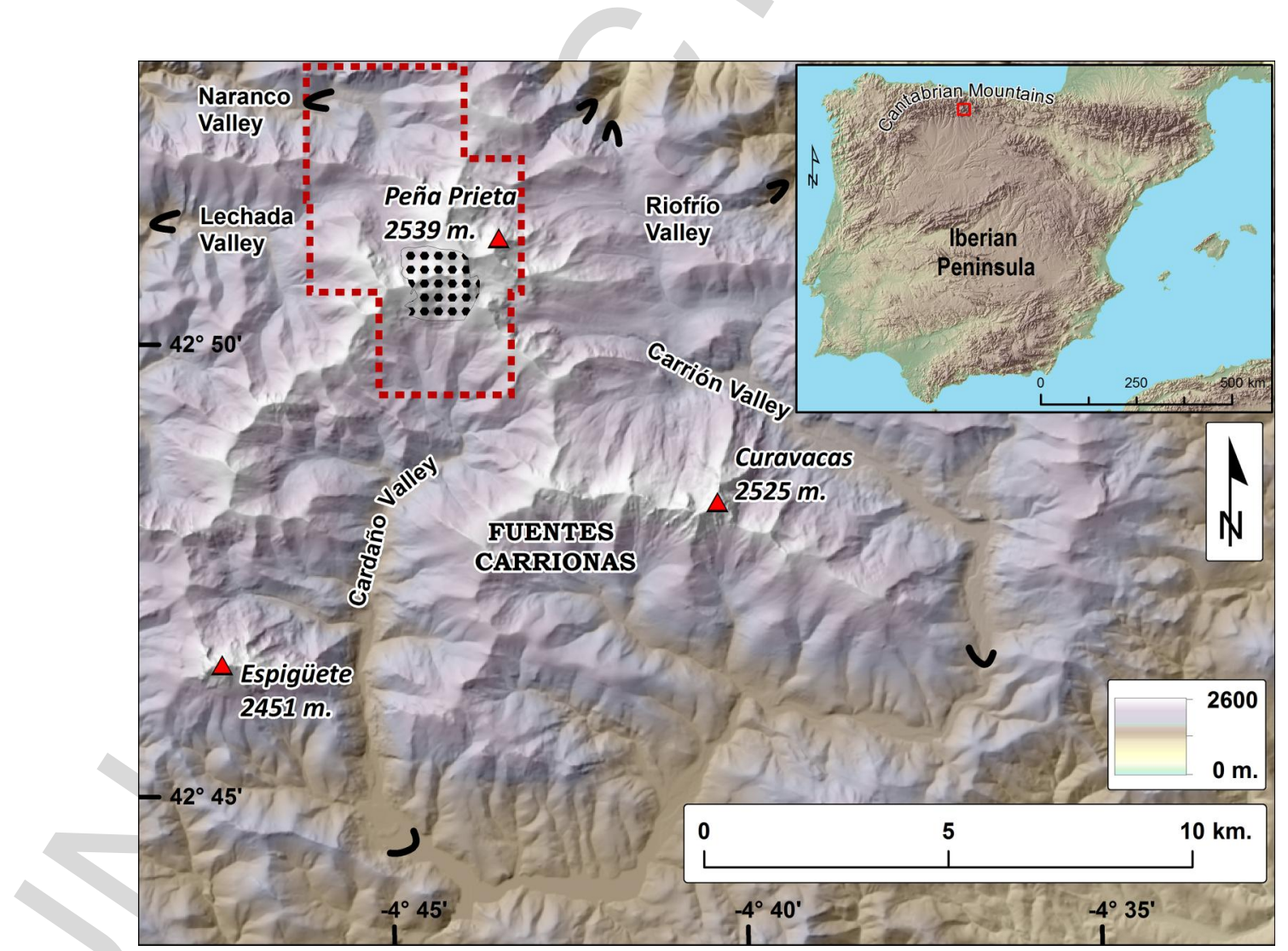

Figure 1. Location of the FC massif within the Iberian Peninsula. The black-dotted polygon indicates the granodiorite outcrop. Plain thick lines depict the location of glacier fronts during their maximum extent, according to Pellitero (2013). The dashed polygon corresponds to the limits for Fig. 3. 
$\left(42.92^{\circ} \mathrm{N}, \quad-4.68^{\circ} \mathrm{W}, 1290 \mathrm{~m}.\right)$, receives $1043 \mathrm{~mm}$ AAP, whereas MAAT is $8.1^{\circ} \mathrm{C}$ and seasonality is $14.7^{\circ} \mathrm{C}$ (Pellitero, 2012).

FC features a varied - mostly sedimentary - lithology, which was deposited thorough the Palaeozoic. Conglomerate, shale, quartzite, sandstone and limestone are typical. The highest peaks and valley tops are usually carved from Curavacas conglomerate, which was deposited during the Variscan Orogeny ( 300 Mya). It consists of rounded pebbles and cobbles, mostly quartzitic, although sandstone and limestone clasts are also present, in a very hard sandy matrix. At the centre of the range, around Peña Prieta, there is a $4-\mathrm{km}^{2}$ granodiorite outcrop of Permian age, which resulted from an intrusion during a cortical thinning stage after the Variscan Orogeny (Gallastegui et al., 1990). This granodiorite outcrops just in the Lechada, Cardaño and Carrión watersheds; therefore, granodiorite erratics provide good evidence of transport from these valleys' headwalls (Fig. 1).

\section{Materials and methods}

\section{Sampling strategy and sample processing}

Seven samples were collected for cosmic-ray exposure (CRE) dating, from which six were suitable for dating (Figs. 2 and 3; Table 1). The ${ }^{10} \mathrm{Be}$ isotope was chosen due to the presence of quartz in the lithology (granodiorite and Curavacas conglomerate). Three boulders from the Naranco frontal moraine complex were sampled. This moraine complex includes numerous granodiorite moraine boulders in a watershed where no granodiorite outcrops occur. Therefore, it marks a moment when a glacial transfluence from Lechada Valley through the Boquerón de Bobias pass was active, providing granodiorite material (Fig. 3; Pellitero, 2014). Two samples were collected from boulders sitting on the Lechada valley lateral moraine. This moraine stretches beneath the glacial transfluence from the Lechada valley to the Naranco valley (Fig. 3). It marks a moment when the Lechada glacier was not thick enough to provide granodiorite boulders to the Naranco valley; hence, this lateral moraine is younger than the Naranco moraine complex from a morphostratigraphical point of view (Pellitero, 2014). Lom-2 was collected from a glacial threshold immediately downslope of Lomas tarn, in the Cardaño valley (Fig. 3). Lomas tarn is limited by an ice-polished area on its southern tip, carved in conglomerates of the Curavacas Formation.

Samples were taken from gentle flat-topped surfaces on moraine boulders and glacially polished outcrops by using a hammer and a chisel. Well-protruding and well-embedded moraine boulders were considered suitable and highly reliable for dating, as they would be expected to have been stable, so the likelihood of post-glacial overturning or later exhumation is minimized. This procedure limited the selection of boulders
1 


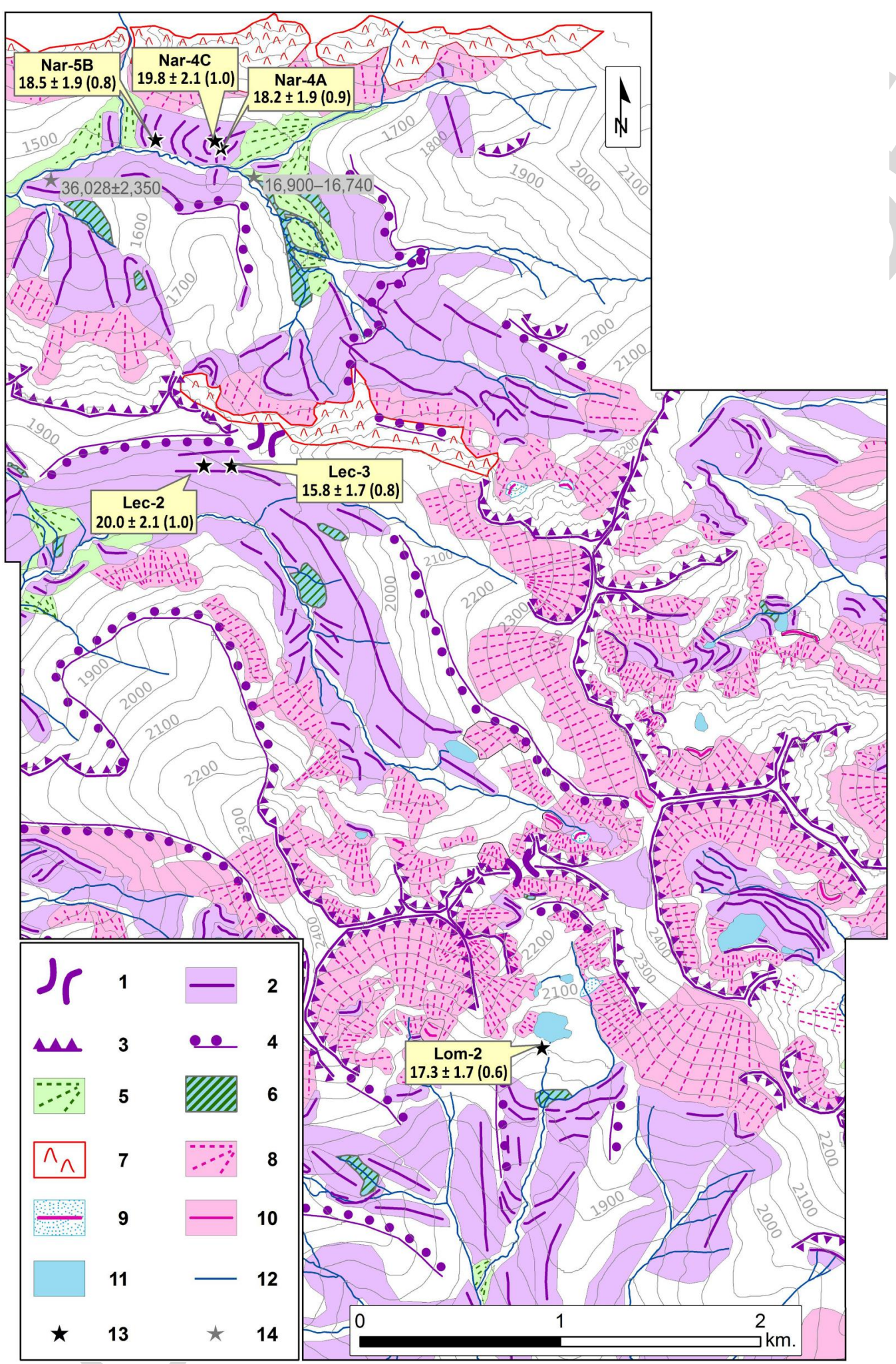

Figure 3. FC glaciomorphological map and dates. 1, lacial transfluence; 2 , moraine ridge; 3 , glacial cirque; 4, glacial shoulder; 5 , glaciofluvial or fluvial fan; 6 , palaeolake deposit; 7 , conglomerate tors; 8 , scree; 9 , protalus rampart; 10 , rock glacier; 11 , lake; 12 , river/stream; $13,{ }^{10} \mathrm{Be}$ sample; 14 , previous dates published by Serrano et al. (2013).

suitable for sampling, but strengthened the dating results by following geomorphological criteria rather than statistical methods, in accordance with Palacios et al. (2019).

Likewise, high and upstanding polished surfaces were chosen to prevent the possibility of soil cover, which could have attenuated cosmic-rays at the rock surface.

Physical and chemical processing of samples was performed in the ETH Zurich Laboratory of Ion Beam Physics. First, samples were crushed, ground and sieved to optimal grain size. Chemical processing started by leaching the samples with hydrofluoric (HF), hydrochloric and nitric acids. Magnetic separation for quartz isolation from bulk rock was performed for samples Nar-5B, Nar-4A and Lec-2. The amount of processed quartz for ${ }^{10} \mathrm{Be}$ sampling ranged between 16.7 and $22.3 \mathrm{~g}$. Quartz purification comprised several HF baths; $0.25 \mathrm{mg}$ of a ${ }^{9} \mathrm{Be}$ carrier was added to the samples before the total dissolution of quartz by HF acid leaching. Beryllium was separated from other elements by using cationic and oxalic 


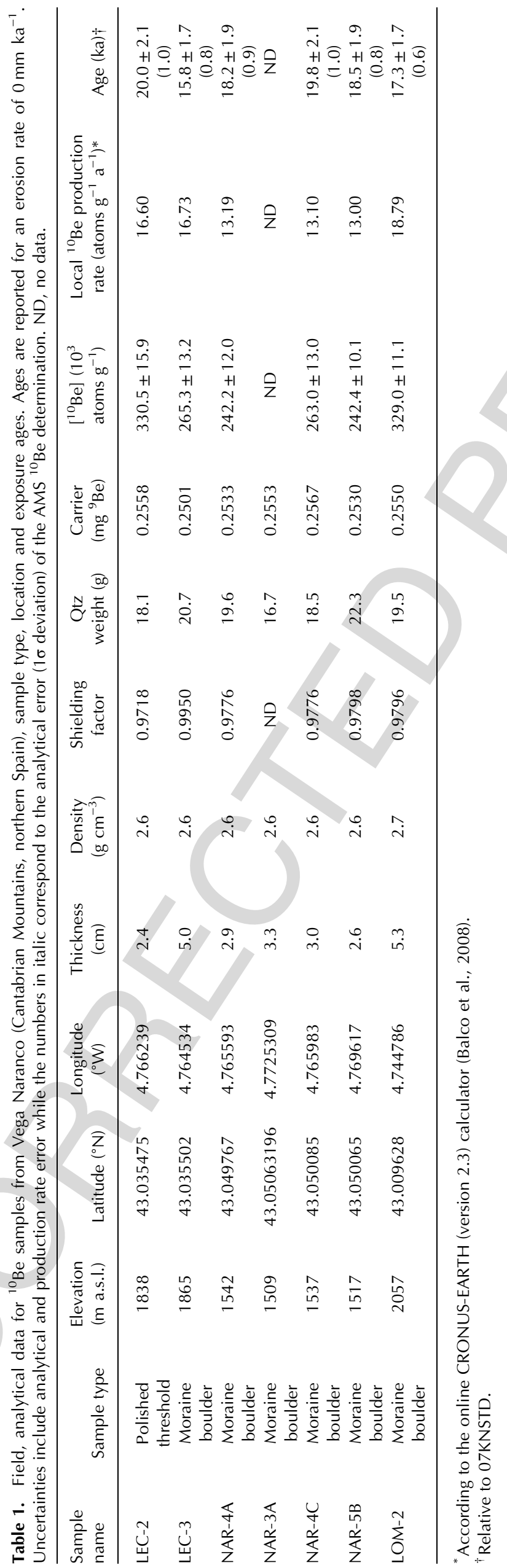

1
2
3
4
5
6
7
8
9
10
11
12
13
14
15
16
17
18
19
19
20
21
22
23
24
25
26
27
28
29
30
31


columns. Beryllium was precipitated to $\mathrm{Be}(\mathrm{OH})_{2}$ by means of ammonia. The samples were transferred to quartz crucibles and oxidized at $800^{\circ} \mathrm{C}$, then pressed into targets. The final $\mathrm{BeO}$ targets were analysed at the ETH accelerator mass spectrometry (AMS) facility to infer the ${ }^{10}$ Be concentrations from the ${ }^{10} \mathrm{Be} /{ }^{9} \mathrm{Be}$ ratios.

AMS measurements were normalized to the in-house secondary ${ }^{10} \mathrm{Be}$ standards S2007N and S2010N, with nominal values of ${ }^{10} \mathrm{Be} /{ }^{9} \mathrm{Be}=28.1 \times 10^{-12}$ and $3.3 \times 10^{-12}$, respectively. Both standards have been calibrated with the primary standard ICN01-5-1, with a nominal ${ }^{10} \mathrm{Be} /{ }^{9} \mathrm{Be}$ value of $2.709 \times 10^{-11}$ (Nishiizumi et al., 2007). A ${ }^{10} \mathrm{Be}$ half-life of $1.387 \pm 0.012 \times 10^{6}$ years has been assumed for the results normalized to the above-mentioned standards (Chmeleff et al., 2010; Korschinek et al., 2010).

We calculated surface exposure dates from ${ }^{10} \mathrm{Be}$ measurements using the calculation methods integrated in the CRONUS-Earth (version 2.3) online surface exposure ages calculator (Balco et al., 2008), based on the time-dependent $\left(' \mathrm{Lm}^{\prime}\right)$ scaling scheme (Lal, 1991) and the reference ${ }^{10} \mathrm{Be}$ spallation production rate of 3.92 atoms ${ }^{10} \mathrm{Be}^{-1} \mathrm{a}^{-1}$, derived from the primary calibration dataset in Borchers et al. (2016).

A topographic shielding factor was calculated with the topographic shielding factor calculator included in the CRONUS-Earth calculators (available online at: www. stoneage.ice-d.org/math/skyline/skyline_in.html). Exposure age results are reported for a $0-\mathrm{mm}$ erosion scenario. Snow shielding corrections were not implemented as no data on snow coverage, duration and thickness are currently available. Thus, exposure ages should be considered only as minimum ages (see Palacios et al., 2019). Likewise, no corrections for vegetation cover were implemented.

\section{Palaeoglacier and palaeoclimate reconstruction}

A 3D glacial surface for each phase, either dated or inferred from morphostratigraphy (the case of YD) was reconstructed using glacial landforms and deposits, which had been previously mapped (Pellitero, 2014) and whose morphostratigraphical relationship had previously been described (Pellitero, 2013). Glacier surface reconstruction for each of the phases was performed using GlaRe (Pellitero et al., 2016), which is based on the Benn and Hulton (2010) approach. A standard $100-\mathrm{kPa}$ shear stress was assumed, unless geomorphological evidence (such as lateral moraines) suggested otherwise. In this case shear stress was tuned within a range between 25 and $125 \mathrm{kPa}$, to make the glacial surface match the geomorphological record. The equilibrium-line altitude (ELA) was calculated for each reconstructed phase using the automatic ELA calculation GIS-tool (Pellitero et al., 2015), which generated the ELA values for the accumulation/area ratio and accumulation/area balance ratio (AABR) methods. AABR was chosen for best describing glacier surface mass balance (Rea, 2009), and a 1.7 balance ratio, resulting from the global average balance ratio (Rea, 2009), was chosen.

To quantify palaeoclimatic anomalies, a current climatic scenario for the study area must be known. Given the absence of weather stations within FC, MAAT, AAP and seasonality have been modelled from five weather stations scattered around the mountain range, which are placed at different altitudes (from 270 to $1290 \mathrm{~m}$ ), so a lapse rate can be retrieved and applied over the mountain altitude gradient (Supporting Information, Appendix S1). All climatic data were downloaded from the Spanish GIS online server for Agrarian Data (Ministerio de Medio Ambiente, 2018). It must be stressed that both MAAT and AAP appear to be closely related to altitude, but that seasonality is latitude-dependent. With the
Cantabrian coast having a meridian-running orientation in this part of the Iberian Peninsula, and the Atlantic coast being much further away than the Cantabrian coast, latitude can be assumed as distance to the sea, and hence the reason for seasonality being so latitude-driven (Appendix S1).

AAP during the glacial advance phases were calculated from the relationship between 3-month summer temperatures and annual precipitation at the ELA described by Ohmura et al. (1992), which remains the best glacier-climate relationship dataset available. Palaeotemperatures were retrieved from different palaeoclimatic proxies close to the study area. No single palaeoclimate proxy was used, as none of them covered the entire timespan of FC glacier advance phases. The closest proxy is mammal assemblages from El Mirón cave, which is situated $105 \mathrm{~km}$ northeast of FC. By studying the mammal species that lived in the area, the temperature and precipitation regime in which these mammals thrived can be retrieved (Bañuls-Cardona et al., 2014). El Mirón cave provided temperature data for the 18-20 ka, but Bañuls-Cardona et al. (2014) also offer temperature data for the 17.8-17.7 ka chronozone based on Valdavara cave, located $197 \mathrm{~km}$ to the west of FC. These values have also been discussed. Sea-surface temperatures (SSTs) from alkenones and foraminifera in two cores near the NW Iberian coast (core MD99-2331 42.15 $\mathrm{N}$, $-9.69^{\circ} \mathrm{W} ; 2110-\mathrm{m}$ depth, Naughton et al., 2009) and in the Bay of Biscaye (core MD04-2845, $45.35^{\circ} \mathrm{N},-5.216667^{\circ} \mathrm{W}$, -4100 m, Sánchez Goñi et al., 2008), respectively, as well as chironomid-inferred July temperatures (Muñoz Sobrino et al., 2013) provided more palaeotemperature proxies. Current annual SSTs for the NW Iberian Peninsula coasts are around $15.5^{\circ} \mathrm{C}$ (Abrantes et al., 2017), which mirrors the MAAT for the NW Iberian coast, e.g. La Coruña $\left(43.36^{\circ} \mathrm{N},-8.40^{\circ} \mathrm{W} ; 14.2^{\circ} \mathrm{C}\right)$ or Vigo $\left(42.23^{\circ} \mathrm{N},-8.72^{\circ} \mathrm{W} ; 14.9^{\circ} \mathrm{C}\right)$. Finally, the $\mathrm{Mg} / \mathrm{Ca}$ ratio and $\delta^{18} \mathrm{O}$ record in speleothems (Moreno et al., 2010a) and geochemistry of proglacial lake deposits (Moreno et al., 2010b) have provided a qualitative climatic context as well. All palaeotemperature data were transformed into ELA temperature data using a standard lapse rate of $0.006^{\circ} \mathrm{C} \mathrm{m}^{-1}$.

Summer average temperature was retrieved from either the warmest month average temperature (WMAT) or MAAT. As Ohmura et al. (1992) describe precipitation at the ELA from the summer average temperature (SAT), a seasonality value is needed to transform WMAT or MAAT into SAT. Seasonality has been regarded as an important factor in glacier extension for the Iberian Peninsula at least during the OD and YD phases (Palacios et al., 2016; Rea et al., 2017). Given the general impossibility to calculate seasonality during the period of glacier advance, we calculated current seasonality values to tune our palaeoclimatic reconstruction. Nowadays seasonality in the study area is $14.4^{\circ} \mathrm{C}$ (Appendix S1). This value has been used in palaeoclimate reconstruction of the LME, LGM and OD phases. Given the higher seasonality during the YD (Lie and Paasche, 2006; Schenk et al., 2018) compared to today, a $25 \%$ seasonality increment was applied on this event.

\section{Dating results and inferred glacial dynamics}

The Vega Naranco moraine complex can be dated to the end of the LGM (sensu Mix et al., 2001), between $18.2 \pm 0.9$ and $19.8 \pm 2.1$ ka (Table 1; Fig. 3). It would therefore mark a second advance phase after the LME, dated at 36 ka (Serrano et al., 2013). The three boulders were dated within the internal error range, Nar-4A and Nar-5B being practically coeval, whereas the date for Nar-4C is around 1.5 ka older. Both dated moraines can be assumed as contemporaneous or revisited during glacial readvances that reached a very similar extension during the 20-18 ka chronozone. Given the high proportion of 
granodiorite boulders that travelled from the Peña Prieta area through the Boquerón de Bobias pass, it can be assumed that the Lechada glacier extension was also close the maximum, to have enough ice thickness to outflow into the Naranco valley.

Samples from the Lechada valley show a large timing gap of more than $4 \mathrm{ka}$, despite being sampled from two boulders within the same moraine, just below the Bobias glacial transfluence. From a morphostratigraphical point of view, the moraine can therefore be dated to after the aforementioned Naranco moraine complex. However, Lec-2 suggests the opposite, making the Lechada lateral moraine coeval with the Naranco frontal complex. In this case, the boulder sampled in Lec-3, which was collected from the same moraine as Lec2 , would have been buried and exhumed later, giving a misleading age of $15.8 \pm 0.8 \mathrm{ka}$. Alternatively, we can assume that Lec- 2 was sampled from a boulder that was plucked or revealed by the glacier that occupied Lechada during the 19-21 ka advance and subsequently moved to its current position by the glacier that developed roughly 4 ka later. This second alternative would give a $15.7 \pm 0.8 \mathrm{ka}$ age to the lateral moraine and the frontal moraine located at $1700 \mathrm{~m}$ in the Lechada valley (Fig. 4), and therefore to the subsequent retreat phase after the 19-21 ka event. This is our preferred option given its morphostratigraphical consistency.

The exposure age result from the Lomas roche mountonnée reveals the pattern of retreat on a less favourable south-facing part of the massif. Due to an earlier deglaciation in this area, compared to the Lechada valley immediately north of the Lomas valley, by $17.3 \pm 0.6 \mathrm{ka}$ the glacier front had already retreated at least to the area were Lomas lake is located.

\section{Glacier reconstruction and ELA calculation}

A 91.4- $\mathrm{km}^{2}$ ice field was reconstructed for the LME (Fig. 4). The glacial ELA for the LME phase was $1797 \mathrm{~m}$ (AABR 1.7). The small ice cap at the watershed between the Carrión, Riofrío, Lomas and Lechada valleys, which was suggested by Pellitero (2014), is no supported by the glacier surface model run in a general $100 \mathrm{kPa}$ shear stress scenario. However, transfluence between the Lechada and Lomas valleys was confirmed, which also matches the geomorphological record.

During the LGM, glaciers progressed to positions very close to those reached by the LME advance. Nevertheless, ice thicknesses would have been considerably lower, according to
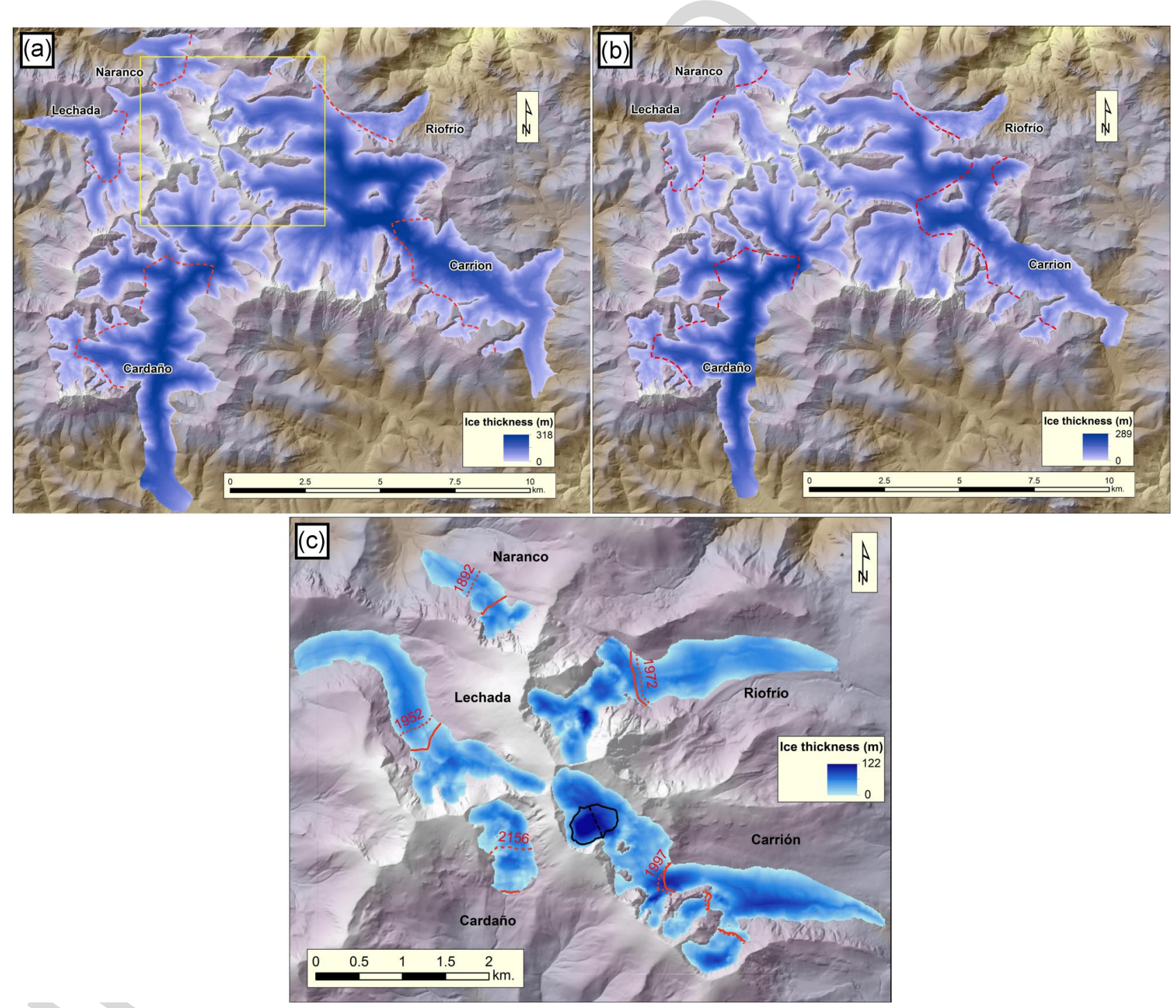

Figure 4. (a) Glacier extent during the LME. Blue gives glacier extent during the LME. Red-dashed lines represent the regional 1.7 AABR ELA for the LME at $1797 \mathrm{~m}$. The yellow square marks the bottom map. (b) Glacier covered area during the LGM. Red-dashed lines show its 1.7 AABR ELA at $1806 \mathrm{~m}$. (c) Glacier-covered area during the OD. Red lines represent the regional 1.7 AABR ELA for the OD at $1987 \mathrm{~m}$, whereas red-dashed lines show the 1.7 AABR for each glacier. The black line shows the extent of the Laguna de Fuentes Carrionas glacier during the YD, while the blackdashed line shows its 1.7 AABR ELA at $2265 \mathrm{~m}$. Note that other glaciers developed elsewhere in the area during the YD have not been depicted. 
the geomorphological record. The ELA is therefore very similar to the former phase, $1806 \mathrm{~m}$ (AABR 1.7) for a glacier that was less extensive $\left(77 \mathrm{~km}^{2}\right)$. After this advance phase, glaciers quickly retreated to higher positions, so by $16 \mathrm{ka}$, for example, the Vega Naranco valley bottom was ice-free, and occupied by a lake (Serrano et al., 2013).

A significantly less extensive glacier advance phase can be identified in all valleys. Glaciers were reduced in length to $5 \mathrm{~km}$ for the largest, the Carrion glacier. The regional ELA for this third phase was at $1987 \mathrm{~m}$ if we consider the FC as a whole. However, glaciers located on the northern part show a significantly lower ELA than southern orientated glaciers, suggesting differential snow feed between northern and southern glaciers, perhaps caused by wind blow, or the effect of differential net shortwave radiation on northern and southern glaciers, which is a crucial factor for snowmelt in temperate glaciers nowadays (Sicart et al., 2008). Lec-3 and Lom-1 suggest that this advance phase occurred during the OD.

Finally, a cirque glacier phase can be identified at the highest glacial cirques of the massif. The clearest frontal moraine is located at the Laguna de Fuentes Carrionas cirque, which nowadays forms a small lake at $2200 \mathrm{~m}$. The glacier that deposited the Laguna de Fuentes Carrionas moraine has been reconstructed, yielding a $2265 \mathrm{~m}$ ELA (AABR 1.7). We assume this phase to have occurred during the YD event, although no direct date has been retrieved.

\section{Discussion: FC glacial evolution and its implications for glacier dynamics and palaeoclimate}

Our results show a coherent pattern of glacier retreat with nearby Cantabrian Mountain areas (Serrano et al., 2016; Rodríguez-Rodríguez et al., 2017). When compared to other areas of the Iberian Peninsula, glaciation in the FC shows a similar pattern, but with some timing differences. Our results complement the palaeoenvironmental picture of the Iberian Peninsula in the Late Pleistocene. Given glacier extension, ELAs and palaeoproxy-inferred MAAT, the amount of AAP necessary for palaeoglacier preservation during the four identified and dated glacial advance stages was lower than today except for the LGM (Table 2; see Appendix S2 for details).

The LME has been dated as a pre-LGM phase in every Cantabrian Mountain area where glacial advance dating has been performed, regardless of the dating method (Rodríguez-Rodríguez et al., 2015, 2018). However, a coeval glacial maximum has not been identified, so, for the glaciers located west of the FC, the LME occurred before 43 ka in the Sil valley (Jalut et al., 2010); $113 \mathrm{ka}$ in the Porma valley (Rodríguez-Rodríguez et al., 2016), with a near-maximum advance at $56 \mathrm{ka}$ (Rodríguez-Rodríguez et al., 2016, 2018); and $45 \mathrm{ka}$ in the Picos de Europa (JiménezSánchez et al., 2013). The LME dates for Castro Valnera, east of the FC, yielded ages between 40.4 and $78.5 \mathrm{cal}$ a BP (Frochoso et al., 2013) in its northern watershed, and before $29 \mathrm{cal}$ a BP in the south (Serrano et al., 2013).

According to Sánchez Goñi et al. (2008), the 37-36 ka millennium coincides with the GS-8 stadial, marked by low sea temperatures and a general aridity on the western margins of the Iberian Peninsula and the Bay of Biscay. SSTs at the Bay of Biscay plummeted to values as low as $4^{\circ} \mathrm{C}$ during the warmest season. Mean SSTs would be $2.5^{\circ} \mathrm{C}$ (Fig. 5). By $36 \mathrm{ka}$, when the LME is dated in the FC, annual SSTs had increased slightly to $4.5^{\circ} \mathrm{C}$. Extraordinary sea ice advance during this period would have pushed westerlies further south, thus bringing moister conditions to the southern Iberian Peninsula. Fletcher et al. (2010) have found pollen deposition maxima for the Alborán Sea during at $36 \mathrm{ka}$. Likewise, the Iberian Peninsula would have been among the wettest areas in Europe, according to the modelled results by Van Meerbeeck et al. (2011). We have reconstructed annual precipitation as low as $713 \mathrm{~mm}$ for the ELA during the LME, suggesting tundralike conditions in the area, with an $-11.5^{\circ} \mathrm{C}$ MAAT anomaly, and average temperatures below zero year-round, except the warmest month, at the ELA. Nevertheless, it must be stressed that these conditions could have sustained the glacier at the LME, but glacial advance would have started under the aforementioned cold conditions during 36-37 ka (Sánchez Goñi et al., 2008) to obtain this spread. This would probably have occurred under a higher precipitation regime at the onset of the cold event.

An LGM glacial advance has also been identified elsewhere in the NW Iberian Peninsula. A lateral moraine in Sanabria was dated to between 21.8 and 19.2 ka (Rodríguez-Rodríguez et al., 2014); and a lateral moraine was dated at the Brañagallones valley to between 24 ka (Jiménez-Sánchez et al., 2013) and 18 ka (Rodríguez-Rodríguez et al., 2017), which is part of the same ice field as the mentioned Porma valley. A later study in the Porma valley confirmed that glaciers still flowed down to $1130 \mathrm{~m}$ a.s.l. at 20.2 ka (RodríguezRodríguez et al., 2018). An LGM readvance imprint is clear in the Central Range (Palacios et al., 2012; Carrasco et al., 2015). In the FC, the LGM phase is marked by a very similar glacier length, for generally lower ice thickness. One of the main reasons could have been a lower shear stress for the glacier, which flowed on the soft sediments deposited during the previous LME glaciation, which would have entailed enhanced basal sliding and ice flow acceleration, a situation that has also been found elsewhere (Gribenski et al., 2016, and references therein). Unlike the $L M E$, the LGM would have been characterized by relatively high sea temperatures (Fig. 5). Bañuls-Cardona et al. (2014) support the idea of a wet LGM at the Cantabrian Margin, and this is also suggested by Moreno

Table 2. Climate anomalies reconstructed from ELA precipitation-temperature relationships and other temperature palaeoproxies. All climatic values are referred to the ELA level.

\begin{tabular}{|c|c|c|c|c|c|c|c|c|}
\hline Phase & $\operatorname{ELA}(\mathrm{m})$ & $\begin{array}{l}\text { AAP } \\
(\mathrm{mm})\end{array}$ & MAAT $\left({ }^{\circ} \mathrm{C}\right)$ & $\begin{array}{c}\text { Current } \\
\text { AAP (mm) }\end{array}$ & $\begin{array}{c}\text { Current } \\
\text { MAAT }\left({ }^{\circ} \mathrm{C}\right)\end{array}$ & $\begin{array}{c}\text { AAP } \\
\text { anomaly }(\mathrm{mm})\end{array}$ & $\begin{array}{c}\text { MAAT } \\
\text { anomaly }\left({ }^{\circ} \mathrm{C}\right)\end{array}$ & $\triangle \mathrm{AAP}(\%)$ \\
\hline $\begin{array}{l}\text { Younger Dryas } \\
(12.4 \mathrm{ka})\end{array}$ & 2265 & 1311 & -6.1 & 1332 & 3.1 & -21 & -9.0 & -2 \\
\hline $\begin{array}{c}\text { Oldest Dryas } \\
(15.7 \mathrm{ka})\end{array}$ & 1987 & 839 & -5.9 & 1247 & 4.5 & -408 & -10.4 & -33 \\
\hline LGM (18.7 ka) & 1806 & 2633 & -0.8 & 1192 & 5.4 & 1441 & -6.2 & 121 \\
\hline LME (36 ka) & 1797 & 713 & -6.2 & 1189 & 5.4 & -476 & -11.6 & -40 \\
\hline
\end{tabular}

*Only for the Laguna de Fuentes Carrionas glacier. 


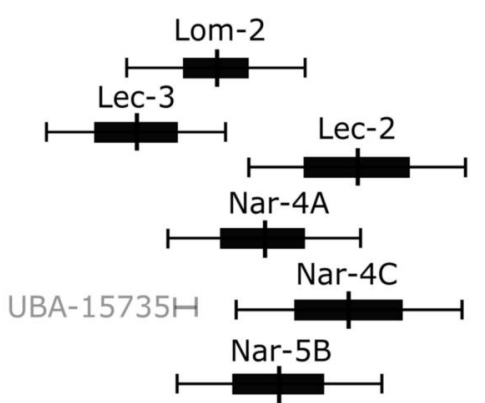

MAD-5980SDA

(a)
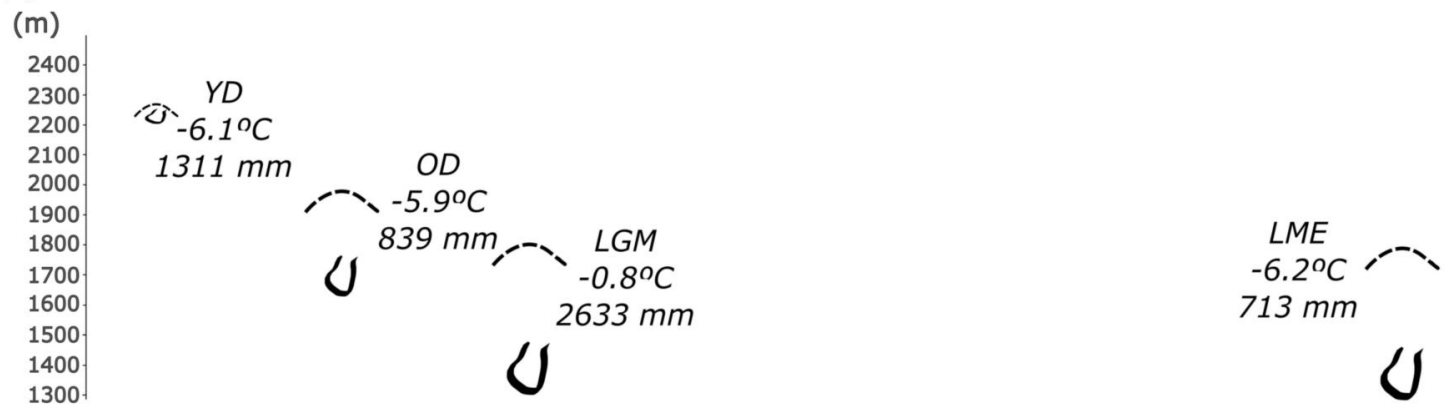

(b)

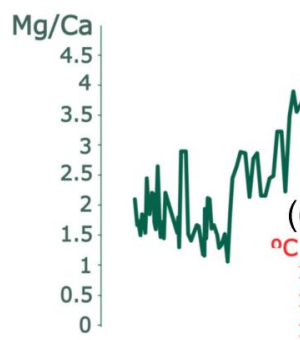

(d)

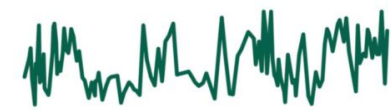

c)
${ }^{\circ} \mathrm{C} 18$.

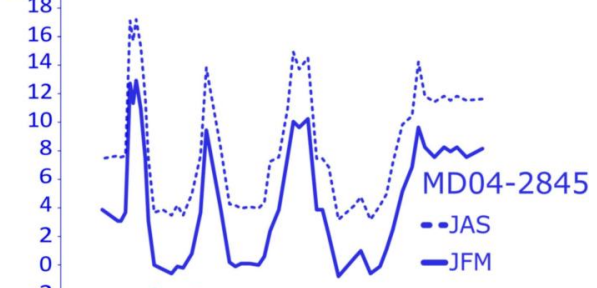
$100 \mathrm{~km}$ NW of our study area, although the interval between 19 and $18 \mathrm{ka}$ would have been relatively drier, according to the $\mathrm{Mg} / \mathrm{Ca}$ record. Luetscher et al. (2015) suggest that storm tracks would have shifted south at the LGM, generating a general southerly moisture source for precipitation in the Alps, which is in accordance with atmospheric circulation models for the LGM, such as Strandberg et al. (2011). It must be stressed that Strandberg et al. (2011) prescribe a $1500 \mathrm{~m}$ ELA for the Cantabrian Mountains in their model, which is accurate for glaciers west of the study area, but too low for the FC. In terms of temperatures, they clearly dropped around 20 ka with no significant change in precipitation compared to previous millennia (Moreno et al., 2010a), which would have triggered glacier advance. The end of this phase is marked in the lacustrine sediments of Enol Lake at 19 ka (Moreno et al., 2010b), when an increase in the total organic carbon (TOC) content points to glacier fronts further upland and more vegetation in the catchment.

The climate reconstruction modelled by Strandberg et al. (2011) ( 21 ka) proposes a polar desert environment for the FC at the LGM, with average temperatures below zero year-round and extremely low precipitation at the ELA. An extremely dry climate would entail enhanced seasonality. A scenario with current seasonality would still yield low precipitation at the ELA, around $479 \mathrm{~mm}$. Regardless, the climate conditions proposed by Strandberg et al. (2011) do not meet any of the previously mentioned proxies, so they can be dismissed. Conversely, the reconstructed climate from mammal assemblages of Bañuls-Cardona et al. (2014) would mean a hyperhumid climate in which precipitation at ELA increases to $4338 \mathrm{~mm}$, which is also not feasible. Climate can be assumed between these two boundaries. The alkenone-based reconstruction by Naughton et al. (2009) gives annual SSTs of $10^{\circ} \mathrm{C}$ between 18.5 and 19 ka (Appendix S2). Under these temperatures at sea level, MAAT would be around $-1{ }^{\circ} \mathrm{C}$ at the ELA. In such conditions, precipitation at the ELA would be significantly higher than current values, at around $2660 \mathrm{~mm}$, be in accordance with other palaeoclimatic proxies (Moreno et al., 2010a) and with the palaeoclimatic scenarios proposed from glacier reconstruction further west in the Cantabrian pointing at a cold and humid environment. This climate would 
Mountains (Rodríguez-Rodríguez et al., 2017). It would also match other proxies for the south of the Iberian Peninsula, which give temperatures $5^{\circ} \mathrm{C}$ lower than current values, with a positive precipitation anomaly between 20 and 18 ka (Combourieu Nebout et al., 2009).

The OD (17.5-14.5 ka) advance phase has also been identified elsewhere in the Iberian Peninsula (Palacios et al., 2016). During this phase glaciers advanced and occupied valleys, thus interrupting the continuous retreat experienced after the LGM. For the Porma valley, just $100 \mathrm{~km}$ west of Peña Prieta, Rodríguez-Rodríguez et al. (2016) dated a glacier during the OD (17.6 ka, resulting from the average of 5 erratics) at $1630 \mathrm{~m}$ altitude. Glacier reconstruction for this phase yielded an ELA of $1600 \mathrm{~m}$. A subsequent cold stage in the same area produced a rock glacier, whose front at $1650 \mathrm{~m}$ was dated to $15.7 \mathrm{ka}$, therefore pointing to an ELA rise to 1890 $\mathrm{m}$ in a coeval cirque glacier (Rodríguez-Rodríguez et al., 2016). At nearby Brañagallones, on the north side of the same area, Rodríguez-Rodríguez et al. (2017) dated a lateral moraine situated at $1360 \mathrm{~m}$ to $16.7 \mathrm{ka}$. Glacier reconstruction from this lateral moraine yielded a local ELA of $1560 \mathrm{~m}$. Higher up the valley, a frontal moraine, which would have limited a small cirque glacier with a 1682 m ELA, was dated to $14 \mathrm{ka}$, during the short OD stage (Rodríguez-Rodríguez et al., 2017).

This phase again was extremely cold and dry over the Iberian Peninsula (Dormoy et al., 2009; Fletcher et al., 2010; Rodrigo-Gámiz et al., 2011). In terms of precipitation, Fletcher et al.'s (2010) palaeoprecipitation reconstructions indicate a tundra environment in the Cantabrian Mountains. Such conditions can be confirmed by the speleothem record in $\mathrm{El}$ Pindal (Moreno et al., 2010a), which shows a deposition hiatus during this event and a deposition resumption by $15.5 \mathrm{ka}$, with very high $\mathrm{Mg} / \mathrm{Ca}$ values (Fig. 5). However, of nore is higher precipitation immediately at the onset of the event in other palaeoenvironmental proxies (Naughton et al., 2016). In the FC, the differential ELA between the north and south slopes would reflect a higher exposure to the sun's radiation on southern slopes, some snow redistribution cause by wind blow, as well as a general decreasing $\mathrm{N}-\mathrm{S}$ precipitation trend, which can also be observed nowadays. There is no record of any glacier advance during the short OD advance in the study area.

Palaeoprecipitation reconstruction for the ELA based on Bañuls-Cardona et al.'s (2014) data for the OD again yields very high precipitation $(>5000 \mathrm{~mm})$, which is not in accordance with the other cited palaeoproxies. Naughton et al. (2009) reconstructed SSTs offshore the Galician coasts from foraminifera, and carried out a pollen count procedure. Their results show summer SST between 8 and $4.5^{\circ} \mathrm{C}$ at the 18-17 ka chronozone, coinciding with the marine $\mathrm{H} 1$ event, and minimal temperate tree and Pinus extension for this period. The OD moraine in Lechada has been dated to 15.8 ka, later during the cold event. Using Naughton et al.'s (2009) SST and local seasonality, annual precipitation at the ELA would be $840 \mathrm{~mm}$, for an average annual temperature around $10^{\circ} \mathrm{C}$ colder than current values at $1987 \mathrm{~m}$. These results propose a tundra-like environment in the $\mathrm{FC}$, with extremely low temperatures and precipitation, which matches the cited palaeoproxies.

The youngest presented date produced an age of $15.8 \mathrm{ka}$. However, a final glacier advance phase did occur in the area, although only in few, very sheltered, north-facing glacial cirques, such as the Laguna de Fuentes Carrionas cirque. In this last phase the climatic ELA might already have been above the peaks. This situation is in accordance with evidence from Rodríguez-Rodríguez et al. (2017), who point to a more reduced YD event than previously expected (see Serrano et al., 2016), in which the ELA would be above the peaks, and a rock glacier developed in the Brañagallones area. It is also in accordance with Serrano et al. (2012), in which a cold phase is clearly distinguished in the lacustrine record of the Áliva palaeolake. Muñoz Sobrino et al. (2013) proposed a cold but not dry environment for the YD chronozone using pollen, chironomid and diatoms from a small lake in the Sanabria area, $200 \mathrm{~km} \mathrm{SW}$ of the FC. The chironomid-inferred July temperature was $10^{\circ} \mathrm{C}$ at $1608 \mathrm{~m}$ during the $12.5-12.4 \mathrm{ka}$ interval. Based on that temperature, palaeoclimate reconstruction at the $2265 \mathrm{~m}$ ELA level shows that the area should receive 5700-mm precipitation to sustain glaciers, which is not possible. The OD-YD MAAT $\triangle T$ would be $1.5^{\circ} \mathrm{C}$, according to Muñoz Sobrino et al. (2013) (with the OD placed at the 15.8 ka chronozone and the YD at its coldest part, $12.4 \mathrm{ka}$ ). The availability of high-resolution palaeoclimatic records for YD has revealed several phases within the event. Dormoy et al. (2009) affirm that, at least for the southern Iberian Peninsula, the coldest conditions occurred at the onset of the YD, with increasing temperatures after $12.4 \mathrm{ka}$. In the absence of direct dates for the YD event in the FC, we assume that the reconstructed Laguna de Fuentes Carrionas glacier maximum extent at the YD occurred during this first subphase. Our climate reconstruction proposes $1332 \mathrm{~mm}$ AAP at the ELA, which is very close to the current precipitation, with $9^{\circ} \mathrm{C}$ lower MAAT. Climate cooling at the YD is considered to have affected winter than more summer temperatures, which remained warm thorough the event, hence producing a high seasonality climate. Likewise, enhanced snowfall and a shorter growing season have been modelled for Western Europe during the event (Schenk et al., 2018), whereas westerlies would have driven a moist climate (Rodrigo-Gámiz et al., 2011). These conclusions are confirmed by our precipitation and temperature anomaly results for the YD.

\section{Conclusions}

The timing of glacial advance phase has been preliminarily constrained for the FC by means of CRE dating ${ }^{10} \mathrm{Be}$ dating. Glacial history and its palaeoenvironmental implications show that LME in the FC occurred at $36 \mathrm{ka}$, when a very cold and dry environment was in place. At this point, glaciers covered 91 $\mathrm{km}^{2}$ of the study area. The second advance stage occurred at the 19.8-18.4 ka time interval, during the European LGM. At this point, glacial style and climatic conditions were completely different. Glaciers advanced over soft sediment to almost the same length as the previous phase, but they were thinner. MAAT at $1806 \mathrm{~m}$ was around $-0.8^{\circ} \mathrm{C}$ and AAP was more than double the current values. After the LGM, glaciers retreated until the $\mathrm{OD}$, during which they advanced slightly. At this stage only short valley glaciers existed. Glaciers were comparatively better fed and more extensive on the northfacing cirques. The OD glacial advance phase was cold and dry, with $-6.1^{\circ} \mathrm{C}$ MAAT temperatures and around $839 \mathrm{~mm}$ AAP at $1987 \mathrm{~m}$ altitude. Finally, glaciers advanced slightly during the YD, although only at the highest and most sheltered cirques of the FC. MAAT would have been $9^{\circ} \mathrm{C}$ lower than nowadays for roughly the same precipitation, to sustain glaciers with an ELA of $2265 \mathrm{~m}$. Overall, palaeoglaciers can confirm or refute some of the reconstructed climate scenarios as unlikely, especially those retrieved from mammal remains, as they could not maintain ice formation in the area. Moreover, these results will help to better constrain LGM palaeoclimatic models, such as Strandberg et al. (2011) or Van 
Meerbeeck et al. (2011), which often rely on modelled palaeoprecipitation scenarios.

Acknowledgements. The following research grants helped fund the research published in this paper: CGL2015-68144-R, by the Spanish National Program for Research, Innovation and Development; Ministry of Innovation, Scottish Alliance for Geosciences, Environment and Society (SAGES) Postdoctoral and Early Career Research Exchanges (PECRE) 2017; and the RGS Dudley Stamp Award 2015 'Ice climate relations during the Late Quaternary in Northern Spain'. We thank M. Christl, S. Ivy-Ochs and O. Kronig at ETH Zürich for their support during sample preparation and for AMS measurements. Dr Manuel Gómez-Lende is thanked for his assistance in the field. Finally, we would like to acknowledge $\operatorname{Dr}$ R. M. Carrasco and an anonymous reviewer for their helpful comments.

Abbreviations. AABR, accumulation-area balance ratio; $\mathrm{AAP}$, average annual precipitation; AMS, accelerator mass spectrometry; CRE, cosmic-ray exposure; ELA, equilibrium-line altitude; FC, Fuentes Carrionas; HF, hydrofluoric; LGM, Last Glacial Maximum; LIA, Little Ice Age; LME, local maximum ice extent; MAAT, mean annual air temperature; OD, Older Dryas; SAT, summer average temperature; SST, sea-surface temperature; WMAT, warmest month average temperature; YD, Younger Dryas..

\section{References}

Abrantes F, Rodrigues T, Rufino M et al. 2017. Historical climate off the Atlantic Iberian Peninsula. Climate of the Past Discussions 2017: 1-40, https://doi.org/10.5194/cp-2017-39

AEMET-IM. 2011. www.aemet.es/es/conocermas/recursos_en_linea/ publicaciones_y_estudios/publicaciones/detalles/Atlasclimatologico. [23 May 2018].

Balco G, Stone JO, Lifton NA et al. 2008. A complete and easily accessible means of calculating surface exposure ages or erosion rates from $10 \mathrm{Be}$ and $26 \mathrm{Al}$ measurements. Quaternary Geochronology 3: 174-195, https://doi.org/10.1016/j.quageo.2007.12.001

Bañuls-Cardona S, López-García JM, Blain H-A et al. 2014. The end of the Last Glacial maximum in the Iberian Peninsula characterized by the small-mammal assemblages. Journal of Iberian Geology 40: 19-27, https://doi.org/10.5209/rev_JGE.2014.v40.n1.44085

Benn DI, Hulton NRJ. 2010. An ExcelTM spreadsheet program for reconstructing the surface profile of former mountain glaciers and ice caps. Computers and Geosciences 36: 605-610, https://doi.org/ 10.1016/j.cageo.2009.09.016

Borchers B, Marrero S, Balco G et al. 2016. Geological calibration of spallation production rates in the CRONUS-Earth project. Quaternary Geochronology 31: 188-198, https://doi.org/10.1016/j.quageo. 2015.01.009

Calvet M, Delmas M, Gunnell $Y$ et al. 2011) Recent advances in research on Quaternary glaciations in the Pyrenees. In Developments in Quaternary, Sciences, Ehlers J, Gibbard PL, Hughes PD (eds). Elsevier: Amsterdam. 127-139. Chapter 11. https://doi.org/10. 1016/B978-0-444-53447-7.00011-8

Carrasco RM, Pedraza J, Domínguez-Villar D et al. 2015. Sequence and chronology of the Cuerpo de Hombre paleoglacier (Iberian Central System) during the Last Glacial cycle. Quaternary Science Reviews 129: 163-177, https://doi.org/10.1016/j.quascirev.2015.09.021

Chmeleff J, von Blanckenburg F, Kossert K et al. 2010. Determination of the $10 B$ half-life by multicollector ICP-MS and liquid scintillation counting. Nuclear Instruments and Methods in Physics Research Section B 268: 192-199, https://doi.org/10.1016/j.nimb. 2009.09.012

Combourieu Nebout N, Peyron O, Dormoy I et al. 2009. Rapid climatic variability in the west Mediterranean during the last 25000 years from high resolution pollen data. Climate of the Past 5: 503-521, https://doi.org/10.5194/cp-5-503-2009

Delmas M, Calvet M, Gunnell Y et al. 2011. Palaeogeography and 10Be exposure-age chronology of middle and Late Pleistocene glacier systems in the Northern Pyrenees: implications for reconstructing regional palaeoclimates. Palaeogeography, Palaeoclimatology, Palaeoecology 305: 109-122, https://doi.org/10.1016/j.palaeo.2011. 02.025
Domínguez-Villar D, Carrasco RM, Pedraza J et al. 2013. Early maximum extent of paleoglaciers from Mediterranean mountains during the last glaciation. Scientific Reports 3: 2034, https://doi.org/ 10.1038/srep02034. [PubMed: 23783658]

Dormoy I, Peyron O, Combourieu Nebout $\mathrm{N}$ et al. 2009. Terrestrial climate variability and seasonality changes in the Mediterranean region between 15000 and 4000 years bp deduced from marine pollen records. Climate of the Past 5: 615-632, https://doi.org/10. 5194/cp-5-615-2009

Fernández-Fernández JM, Palacios D, García-Ruiz JM et al. 2017. Chronological and geomorphological investigation of fossil debriscovered glaciers in relation to deglaciation processes: A case study in the Sierra de La Demanda, Northern Spain. Quaternary Science Reviews 170: 232-249, https://doi.org/10.1016/j.quascirev.2017. 06.034

Fletcher WJ, Sanchez Goñi MF, Peyron O et al. 2010. Abrupt climate changes of the last deglaciation detected in a western Mediterranean forest record. Climate of the Past 6: 245-264, https://doi.org/10. 5194/cp-6-245-2010

Frochoso MR, González-Pellejero R, Allende F. 2013. Pleistocene glacial morphology and timing of Last Glacial cycle in Cantabrian Mountains (Northern Spain): new chronological data from the Asón area. Open Geosciences 5: 12-27, https://doi.org/10.2478/s13533012-0117-8

Gallastegui G, Heredia N, Rodríguez Fernández LR et al. 1990. El 'stock' de Peña Prieta en el contexto del magmatismo de la unidad de Pisuerga-Carrion (Zona Cantábrica, $\mathrm{N}$ de España). Cadernos do Laboratorio Xeolóxico de Laxe 15: 203-217.

García-Ruiz JM, Martí-Bono C, Peña-Monné JL et al. 2013. Glacial and fluvial deposits in the Aragón Valley, Central-western Pyrenees: chronology of the Pyrenean Late Pleistocene Glaciers. Geografiska Annaler: Series A, Physical Geography 95: 15-32, https://doi.org/10. 1111/j.1468-0459.2012.00478.x

García-Ruiz JM, Palacios D, González-Sampériz P et al. 2016. Mountain glacier evolution in the Iberian Peninsula during the Younger Dryas. Quaternary Science Reviews 138: 16-30, https:// doi.org/10.1016/j.quascirev.2016.02.022

Gómez-Ortiz A, Oliva M, Palacios D et al. 2015. The deglaciation of Sierra Nevada (Spain), synthesis of the knowledge and new contributions. Cuadernos de Investigación Geográfica 41: 409-426, https://doi.org/10.18172/cig.2722

González Trueba JJ, Moreno RM, Martínez de Pisón E et al. 2008. "Little Ice Age" glaciation and current glaciers in the Iberian Peninsula. The Holocene 18: 551-568, https://doi.org/10.1177/ 0959683608089209

Gribenski N, Jansson KN, Lukas S et al. 2016. Complex patterns of glacier advances during the Late Glacial in the Chagan Uzun valley, Russian Altai. Quaternary Science Reviews 149: 288-305, https:// doi.org/10.1016/j.quascirev.2016.07.032

Hughes PD. 2018. Little Ice Age glaciers and climate in the Mediterranean mountains: a new analysis. Cuadernos de Investigación Geográfica 44: 15-45, https://doi.org/10.18172/cig.3362

Hughes PD, Gibbard PL. 2015. A stratigraphical basis for the Last Glacial Maximum (LGM). Quaternary International 383: 174-185, https://doi.org/10.1016/j.quaint.2014.06.006

Hughes PD, Woodward JC. 2017. Quaternary glaciation in the Mediterranean mountains: A new synthesis. Geological Society, London, Special Publications 433: 1-23, https://doi.org/10.1144/ SP433.14

Jalut G Turu i Michels V, Dedoubat JJ et al. 2010. Palaeoenvironmental studies in NW Iberia (Cantabrian Range): vegetation history and synthetic approach of the last deglaciation phases in the western Mediterranean. Palaeogeography, Palaeoclimatology, Palaeoecology 297: 330-50.

Jiménez-Sánchez M, Farias J. 2002. New radiometric and geomorphologic evidences of a last glacial maximum older than $18 \mathrm{ka}$ in SW European mountains: the example of Redes Natural Park (Cantabrian Mountains, NW Spain). Geodinamica Acta 15: 93-101.

Jiménez-Sánchez M, Rodríguez-Rodríguez L, García-Ruiz JM et al. 2013. A review of glacial geomorphology and chronology in Northern Spain: timing and regional variability during the Last Glacial cycle. Geomorphology 196: 50-64, https://doi.org/10.1016/ j.geomorph.2012.06.009 
Korschinek G, Bergmaier A, Faestermann T et al. 2010. A new value for the half-life of $10 \mathrm{Be}$ by heavy-ion elastic recoil detection and liquid scintillation counting. Nuclear Instruments and Methods in Physics Research Section B 268: 187-191, https://doi.org/10.1016/j. nimb.2009.09.020

Lal D. 1991. Cosmic ray labeling of erosion surfaces: in situ nuclide production rates and erosion models. Earth and Planetary Science Letters 104: 424-439, https://doi.org/10.1016/0012-821X(91)90220-C

Lie O, Paasche O. 2006. How extreme was northern hemisphere seasonality during the Younger Dryas? Quaternary Science Reviews 25: 404-407, https://doi.org/10.1016/j.quascirev.2005.11.003

Luetscher M, Boch R, Sodemann H et al. 2015. North Atlantic storm track changes during the Last Glacial maximum recorded by alpine speleothems. Nature Communications 6: 6344, https://doi.org/10. 1038/ncomms7344. [PubMed: 25724008]

Mackintosh AN, Anderson BM, Pierrehumbert RT. 2017. Reconstructing climate from glaciers. Annual Review of Earth and Planetary Sciences 45: 649-680, https://doi.org/10.1146/annurev-earth-063016-020643

Ministereo de medio Ambiente. 2018. sig.mapama.es/siga/. [22 May 2018].

Mix AC, Bard E, Schneider R. 2001. Environmental processes of the ice age: land, oceans, glaciers (EPILOG). Quaternary Science Reviews 20: 627-657, https://doi.org/10.1016/S0277-3791(00)00145-1

Moreno A, Stoll H, Jiménez-Sánchez M et al. 2010a. A speleothem record of glacial (25-11.6kyr bp) rapid climatic changes from northern Iberian Peninsula. Global and Planetary Change 71: 218-231, https://doi.org/10.1016/j.gloplacha.2009.10.002

Moreno A, Valero-Garcés BL, Jiménez-Sánchez M et al. 2010b. The last deglaciation in the Picos de Europa National Park (Cantabrian Mountains, Northern Spain). Journal of Quaternary Science 25: 1076-1091, https://doi.org/10.1002/jqs.1265

Muñoz Sobrino C, Heiri O, Hazekamp M et al. 2013. New data on the Lateglacial period of SW Europe: A high resolution multiproxy record from Laguna de la Roya (NW Iberia). Quaternary Science Reviews 80: 58-77, https://doi.org/10.1016/j.quascirev.2013. 08.016

Naughton F, Sánchez Goñi MF, Kageyama M et al. 2009. Wet to dry climatic trend in North-Western Iberia within Heinrich events. Earth and Planetary Science Letters 284: 329-342, https://doi.org/10. 1016/j.epsl.2009.05.001

Naughton F, Sánchez Goñi MF, Rodrigues T et al. 2016. Climate variability across the last deglaciation in NW Iberia and its margin. Quaternary International 414: 9-22, https://doi.org/10.1016/j. quaint.2015.08.073

Nishiizumi K, Imamura M, Caffee MW et al. 2007. Absolute calibration of $10 \mathrm{Be}$ AMS standards. Nuclear Instruments and Methods in Physics Research Section B 258: 403-413, https://doi. org/10.1016/j.nimb.2007.01.297

Ohmura A, Kasser P, Funk M. 1992. Climate at the equilibrium line of glaciers. Journal of Glaciology 38: 397-411, https://doi.org/10. 1017/S0022143000002276

Palacios D, Andrés N, Gómez-Ortiz A et al. 2016. Evidence of glacial activity during the Oldest Dryas in the mountains of Spain. Geological Society, London, Special Publications 433: 11.

Palacios D, Andrés N, Marcos J et al. 2012. Maximum glacial advance and deglaciation of the Pinar valley (Sierra de Gredos, Central Spain) and its significance in the Mediterranean context. Geomorphology 177-178: 51-61, https://doi.org/10.1016/j.geomorph.2012.07.013

Palacios D, de Andrés N, López-Moreno Jl et al. 2015. Late Pleistocene deglaciation in the upper Gállego Valley, Central Pyrenees. Quaternary Research 83: 397-414, https://doi.org/10. 1016/j.yqres.2015.01.010

Palacios D, Gómez-Ortiz A, Alcalá-Reygosa J et al. 2019. The challenging application of cosmogenic dating methods in residual glacial landforms: the case of Sierra Nevada (Spain). Geomorphology 325: 103-118, https://doi.org/10.1016/j. geomorph.2018.10.006

Pellitero R. 2012. uvadoc.uva.es:80/handle/10324/2495. [22 May 2018].

Pellitero R. 2013. Evolución finicuaternaria del glaciarismo en el macizo de Fuentes Carrionas (Cordillera Cantábrica), propuesta cronológica y paleoambiental. Cuaternario y Geomorfología 27: 71-90.
Pellitero R. 2014. Geomorphology and geomorphological landscapes of Fuentes Carrionas. Journal of Maps 10: 313-323, https://doi.org/ 10.1080/17445647.2013.867822

Pellitero R, Rea BR, Spagnolo M et al. 2015. A GIS tool for automatic calculation of glacier equilibrium-line altitudes. Computers and Geosciences 82: 55-62, https://doi.org/10.1016/j.cageo.2015. 05.005

Pellitero R, Rea BR, Spagnolo M et al. 2016. GlaRe, a GIS tool to reconstruct the 3D surface of palaeoglaciers. Computers and Geosciences 94: 77-85, https://doi.org/10.1016/j.cageo.2016. 06.008

Pérez-Alberti A, Valcárcel-Díaz M. 1998) Caracterización y distribución espacial del glaciarismo en el noroeste de la Península lbérica, Las huellas glaciares de las montañas españolas, A Gómez-Ortiz (ed). Universidade de Santiago de Compostela, Servicio de Publicaciones e Intercambio Científico, 17-62.

Rasmussen SO, Bigler M, Blockley SP et al. 2014. A stratigraphic framework for abrupt climatic changes during the Last Glacial period based on three synchronized Greenland ice-core records: refining and extending the INTIMATE event stratigraphy. Quaternary Science Reviews 106: 14-28, https://doi.org/10.1016/j.quascirev. 2014.09.007

Rea BR. 2009. Defining modern day area-altitude balance ratios (AABRs) and their use in glacier-climate reconstructions. Quaternary Science Reviews 28: 237-248, https://doi.org/10.1016/j.quascirev. 2008.10.011

Rea BR, Pellitero R, Spagnolo M et al. 2017. Atmospheric dynamics over Europe during the Younger Dryas revealed by palaeoglaciers. Geophysical Research Abstracts 19: 15038.

Rodrigo-Gámiz M, Martínez-Ruiz F, Jiménez-Espejo FJ et al. 2011. Impact of climate variability in the western Mediterranean during the last 20,000 years: oceanic and atmospheric responses. Quaternary Science Reviews 30: 2018-2034, https://doi.org/10. 1016/j.quascirev.2011.05.011

Rodríguez-Rodríguez L, Domínguez-Cuesta MJ, Rinterknecht $\mathrm{V}$ et al. 2018. Constraining the age of superimposed glacial records in mountain environments with multiple dating methods (Cantabrian Mountains, Iberian Peninsula). Quaternary Science Reviews 195: 215-231, https://doi.org/10.1016/j.quascirev.2018.07.025

Rodríguez-Rodríguez L, Jiménez-Sánchez M, Domínguez-Cuesta MJ et al. 2014. A multiple dating-method approach applied to the Sanabria Lake moraine complex (NW Iberian Peninsula, SW Europe). Quaternary Science Reviews 83: 1-10, https://doi.org/10. 1016/j.quascirev.2013.10.019

Rodríguez-Rodríguez L, Jiménez-Sánchez M, Domínguez-Cuesta MJ et al. 2015. Research history on glacial geomorphology and geochronology of the Cantabrian Mountains, North Iberia (43-42 $\left.\mathrm{N} / 7-2^{\circ} \mathrm{W}\right)$. Quaternary International 364: 6-21, https://doi. org/10.1016/j.quaint.2014.06.007

Rodríguez-Rodríguez L, Jiménez-Sánchez M, Domínguez-Cuesta MJ et al. 2016. Chronology of glaciations in the Cantabrian Mountains (NW Iberia) during the Last Glacial cycle based on in situ-produced 10Be. Quaternary Science Reviews 138: 31-48, https://doi.org/10. 1016/j.quascirev.2016.02.027

Rodríguez-Rodríguez L, Jiménez-Sánchez M, Domínguez-Cuesta MJ et al. 2017. Timing of last deglaciation in the Cantabrian Mountains (Iberian Peninsula; North Atlantic region) based on in situ-produced $10 \mathrm{Be}$ exposure dating. Quaternary Science Reviews 171: 166-181, https://doi.org/10.1016/j.quascirev.2017.07.012

Ruiz-Fernández J, Oliva M, Cruces A et al. 2016. Environmental evolution in the Picos de Europa (Cantabrian Mountains, SW Europe) since the last glaciation. Quaternary Science Reviews 138: 87-104, https://doi.org/10.1016/j.quascirev.2016.03.002

Sánchez Goñi MF, Landais A, Fletcher WJ et al. 2008. Contrasting impacts of Dansgaard-Oeschger events over a Western European latitudinal transect modulated by orbital parameters. Quaternary Science Reviews 27: 1136-1151, https://doi.org/10.1016/j. quascirev.2008.03.003

Santos-González J, Redondo-Vega JM, González-Gutiérrez RB et al. 2013. Applying the AABR method to reconstruct equilibrium-line altitudes from the Last Glacial maximum in the Cantabrian Mountains (SW Europe). Palaeogeography, Palaeoclimatology, Palaeoecology 387: 185-199, https://doi.org/10.1016/j.palaeo.2013.07.025 
Schenk F, Väliranta M, Muschitiello F et al. 2018. Warm summers during the Younger Dryas cold reversal. Nature Communications 9: 1634, https://doi.org/10.1038/s41467-018-04071-5. [PubMed: 29691388] Serrano E, Gómez-Lende M, González-Amuchastegui MJ et al. 2015. Glacial chronology, environmental changes and implications for human occupation during the Upper Pleistocene in the eastern Cantabrian Mountains. Quaternary International 364: 22-34, https:// doi.org/10.1016/j.quaint.2014.09.039

Serrano E, González-Trueba JJ, González-García M. 2012. Mountain glaciation and paleoclimate reconstruction in the Picos de Europa (Iberian Peninsula, SW Europe). Quaternary Research 78: 303-314, https://doi.org/10.1016/j.yqres.2012.05.016

Serrano E, González-Trueba JJ, Pellitero R et al. 2013. Quaternary glacial evolution in the Central Cantabrian Mountains (Northern Spain). Geomorphology 196: 65-82, https://doi.org/10.1016/j.geomorph.2012. 05.001
Serrano E, González-Trueba JJ, Pellitero R et al. 2016. Quaternary glacial history of the Cantabrian Mountains of Northern Spain: A new synthesis. Geological Society, London, Special Publications 433: SP433.8.

Sicart JE, Hock R, Six D. 2008. Glacier melt, air temperature, and energy balance in different climates: the Bolivian tropics, the French Alps, and Northern Sweden. Journal of Geophysical Research 113: D24113, https://doi.org/10.1029/2008JD010406

Strandberg G, Brandefelt J, Kjellström E et al. 2011. High-resolution regional simulation of Last Glacial maximum climate in Europe. Tellus Series A 63: 107-125.

Van Meerbeeck CI, Renssen H, Roche DM et al. 2011. The nature of MIS 3 stadial-interstadial transitions in Europe: new insights from model-data comparisons. Quaternary Science Reviews 30: 3618-3637, https://doi.org/10.1016/j.quascirev. 2011.08 .002
1 